\title{
Chemical composition and quality of some river of Mongol Altai
}

\author{
G.Erdenechimeg', Munguntsetseg ${ }^{2}$
}

\author{
${ }^{1}$ School of Pharmacy, HSUM \\ ${ }^{2}$ Faculty of Chemistry, NUM \\ e-mail:Chimge_5@yahoo.com
}

ABSTRACT: Main ions and guality of Hovd River and, its subrivers were studied.

Keywords: Hovd River, main ions, mineralization

\section{INTRODUCTION}

$\mathrm{T}$ he surface water of Mongolia is classified into three groups according to its watershed; Arctic Ocean, Pacific Ocean and Continental watershed. The continental watershed involves $68 \%$ of the surface area of Mongolia and $40 \%$ of water capacity. The system of Khovd River is in Khyargas Lake Basin. The system of Khovd River involves 99 $\%$ of surface area of Bayan-Ulgii province, $21.0 \%$ of surface area of Khovd province and $21.0 \%$ of surface area of Uvs province. Khovd river is the seventh longest and the fifth largest river in Mongolia. Its source is the top glacials of Altai Tavan Bogd Mountains and it flows to Khar-Us Lake. Several other rivers, Tsagaan, Ikh, Uigar, Sogoo, Sagsai, Khatuu, Khavchig, Shijigt, Uliastai, Shurag, Shiver, whose sources are in the glacials of Altai Tavan Bogd mountains flow to Khovd river.

G.N. Potanin /1883/, B.A. Smernov /1932/, N.D.Bespalov /1951/, Sh.Luwsandorj /1959, 1968/, D.Dawaasuren /1961/, N.Tsend, Sh.Sodnombaljer /1964/, J.Tserensodnom /1971, 1975/, B. Tsendee /1980/, B. Ariyadagva /1985/ did hydrochemical studies from the points of the sample from Hovd river. According to the classification of O.A.Alekin from that research result Khovd river and its subrivers and lakes waters belong to the group of hydrocarbonate with low mineralization and low hardness water. Beside that do some research and summerize some materials, determine the composition water from Mongol Altai mointain, water gualified estimation, defermine pollution source, collect some etalon materials.

\section{EXPERIMENTAL}

Hydrochemical studies of the water samples were done using methods of O.A.Alekin (1973), U.U.Lurie (1971-1947) V.Leite (1975), L.P.Sokolova (1989), L.A.Reznikov (1970), D.Darimaa (1985), A.Munguntsetseg (2003). We have taken samples from the points of Khovd river and its subrivers, and determined the location of groundwater by JPS until October, 2010. We did chemical composition analysis complex in Barnayl Laboratory of water institution in Russia

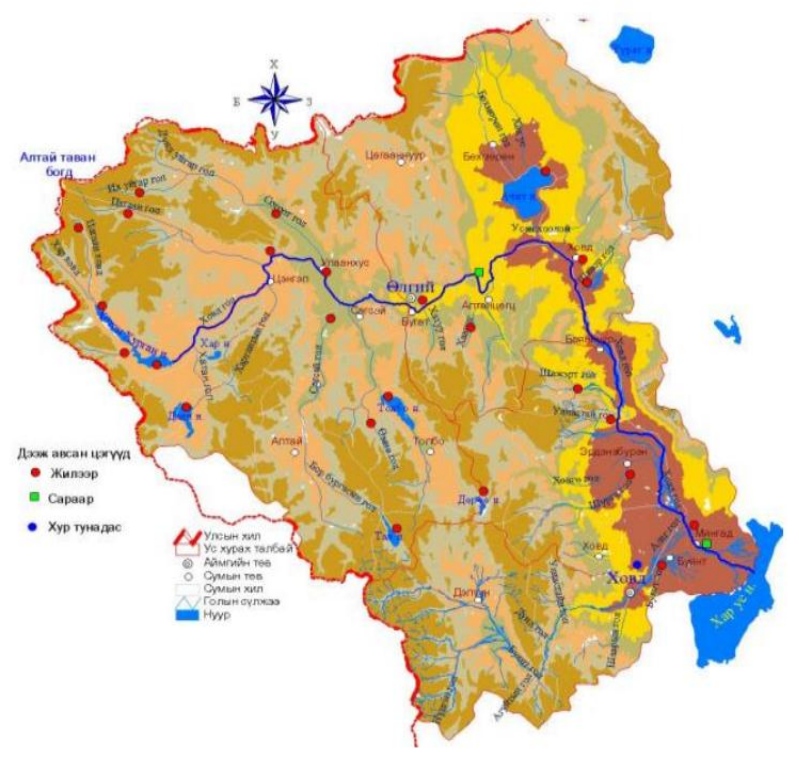

Figure 1. The points of the sample 


\section{RESULTS AND DISCUSSION}

The results of a chemicial experiments are shown in Table 1.

Hovd River: the average sum of its water ions are 207, $55 \mathrm{mg} / \mathrm{dm} 3$. For anions there were hydrocarbonate ions of (85.4-91.5) $\mathrm{mg} / \mathrm{dm} 3$, sulphate ions of $31.00 \mathrm{mg} / \mathrm{dm} 3$, chloride ions of $4.3 \mathrm{mg} / \mathrm{dm} 3$.

For cations there were $15.03 \mathrm{mg} / \mathrm{dm} 3$ of calcium ions, $15.03 \mathrm{mg} / \mathrm{dm} 3$ of natrium and calium ions and $8.51 \mathrm{mg} / \mathrm{dm} 3$ of magnesium ions. The relation of cations and anions was $\mathrm{HCO}-3>\mathrm{SO} 2-4>\mathrm{Cl}-; \mathrm{Na}++\mathrm{K}+>\mathrm{Ca} 2+>$ $\mathrm{Mg} 2+$. The average hardness is $1.45 \mathrm{mg}$-eq /dm3.
The average sum of its water ions $52,9 \mathrm{mg} / \mathrm{dm} 3$. For anions there were hydrocarbonate ions $37.80 \mathrm{mg} / \mathrm{dm} 3$, sulphate ions $0.80 \mathrm{mg} / \mathrm{dm} 3$, chloride ions $1.4 \mathrm{mg} / \mathrm{dm} 3$.For cations there were $10.00 \mathrm{mg} / \mathrm{dm} 3$ calcium ions, $1.5 \mathrm{mg} / \mathrm{dm} 3$ natrium and calium ions and $1.4 \mathrm{mg} / \mathrm{dm} 3 \mathrm{magni}$ ions. The relation of cations and anions - was $\mathrm{HCO}-3$ > Cl- >SO2-4; $\mathrm{Ca} 2+>\mathrm{Na}++\mathrm{K}+>$ $\mathrm{Mg} 2+$. The average hardness is $1.45 \mathrm{mg}$-eq /dm3. According to the classification of O.A.Alekin, this river belongs to the group of hydrocarbonate, class of calcium type and with low minerialization.

Table 1. Chemical composition of Hovd river and water its river bed

\begin{tabular}{|c|c|c|c|c|c|c|c|c|c|c|}
\hline \multirow{2}{*}{ № } & \multirow{2}{*}{ The point of the sample } & & \multicolumn{6}{|c|}{ Main ions $\left(\mathrm{mg} / \mathrm{dm}^{3}\right)$} & \multirow{2}{*}{$\sum_{\mathrm{u}}$} & \multirow{2}{*}{$\begin{array}{c}\text { Index of } \\
\text { Alekin }\end{array}$} \\
\hline & & & $\mathrm{Na}^{+}+\mathrm{K}^{+}$ & $\mathrm{Ca}^{2+}$ & $\mathrm{Mg}^{2+}$ & $\mathrm{HCO}_{\sharp}$ & $\mathrm{SO}_{4}{ }^{2-}$ & $\mathrm{Cl}^{-}$ & & \\
\hline 1 & Potanin ise river & 2010.09.25. & 1.50 & 10.0 & 1.40 & 37.8 & 0.8 & 1.4 & 52.9 & $\mathrm{Cl}_{\mathrm{C}}^{\mathrm{Ca}}$ \\
\hline 2 & Ih uigar river & 2010. 09.26. & 11.96 & 26.6 & 2.04 & 115.9 & 1.0 & 3.57 & 149.11 & $\mathrm{Cl}^{\mathrm{Ca}}$ \\
\hline 3 & Tsagaan river & 2010.09 .27$. & 19.87 & 30.0 & 6.24 & 144.4 & 3.1 & 19.6 & 223.21 & $\mathrm{C}^{\mathrm{Ca}}$ \\
\hline 4 & Ih turgen waterfall & 2010.09 .27 & 5.75 & 22.0 & 1.8 & 68.8 & 1.30 & 12.1 & 106.0 & $\mathrm{C}_{\mathrm{l}}^{\mathrm{Ca}}$ \\
\hline 5 & Ih turgen river & 2010.09 .27$. & 7.13 & 33.5 & 1.56 & 100.0 & 1.50 & 15.4 & 151.98 & $\mathrm{Cl}_{\mathrm{Ca}}^{\mathrm{Ca}}$ \\
\hline 6 & Tsengel sum (Hovd river) & 2010.09 .28 & 2.00 & 7.0 & 1.30 & 28.1 & 0.80 & 2.1 & 41.3 & $\mathrm{Cl}^{\mathrm{Ca}}$ \\
\hline 7 & Sogoo river (ulaan hus sum) & 2010.09 .29 & 14.03 & 30.0 & 4.80 & 127.5 & 2.0 & 13.6 & 191.94 & $\mathrm{Cl}^{\mathrm{Ca}}$ \\
\hline 8 & Hovd river (Bayn-olgii aimag) & 2010.09 .29 & 16.33 & 33.5 & 4.56 & 132.5 & 4.50 & 17.7 & 209.09 & $\mathrm{Cl}^{\mathrm{Ca}}$ \\
\hline 9 & Shurag river & 2010.09 .30 & 20.54 & 40.0 & 11.2 & 169.5 & 23.0 & 19.9 & 284.14 & $\mathrm{Cl}^{\mathrm{Ca}}$ \\
\hline 10 & Hurgan lake & 2010.09 .27 & 23.92 & 23.8 & 2.5 & 115.9 & 2.01 & 17.7 & 185.83 & $\mathrm{Cl}_{\mathrm{C}}^{\mathrm{Ca}}$ \\
\hline 11 & Sirgaliin hooloi & 2010.09 .27 & 16.79 & 26.2 & 3.96 & 110.6 & 2.10 & 18.4 & 178.04 & $\mathrm{Cl}^{\mathrm{Ca}}$ \\
\hline 12 & Hoton lake & 2010.09 .28 & 17.15 & 19.6 & 4.44 & 106.9 & 2.30 & 10.5 & 160.89 & $\mathrm{Cl}^{\mathrm{Ca}}$ \\
\hline 13 & Tolbo lake & 2010.09 .30 & 136.8 & 60.5 & 24.9 & 512.4 & 40.3 & 64.1 & 839.01 & $\mathrm{Cl}_{\mathrm{Na}}^{\mathrm{Na}}$ \\
\hline 14 & Har -Us lake & 2010.09 .28 & 233.9 & 186.3 & 26.7 & 823.5 & 177.5 & 152.0 & 1600.1 & $\mathrm{C}_{\mathrm{l}}^{\mathrm{Ca}}$ \\
\hline 15 & Hurgan lake & 2010.09 .27 & 23.92 & 23.8 & 2.5 & 115.9 & 2.01 & 17.7 & 185.83 & $\mathrm{Cl}_{\mathrm{Ca}}^{\mathrm{Ca}}$ \\
\hline
\end{tabular}

Potanin Ise River. There are many ise rivers in Mongol Altai. They located in 3100-3200 m high. There are 250 ise rivers and cover area is $514 \mathrm{~km} 2$. The largest river is Potanin ise River of Bogd Mountain. Its length is $25 \mathrm{~km}$ and cover area is $47.2 \mathrm{~km} 2$. The water temperature was $-0.14 \mathrm{c} 0$ and measured by automatic thermometers. The joint research team headed by T. Kadota who worked as a research worker in Center for Astronomy of Japan and G.Davaa, as a director, department of Hydrology, Meteorology and Environmental studies installed and marked the poles on the Potanin Glacier to asses the glasier ise accumulation, glacier melt, the amount of precipitation, the temperature and changes to the levels of glacial lake.
Tsagaan River (White). It begins from Potanin icy river of Tavan Bogd mountains and flows into the Hovd River. The average sum of its water ions is $223.21 \mathrm{mg} / \mathrm{dm} 3$. For anions there were hydrocarbonate ions of 144.4 $\mathrm{mg} / \mathrm{dm} 3$, sulphate ions is $3.10 \mathrm{mg} / \mathrm{dm} 3$, chloride ions of $19.60 \mathrm{mg} / \mathrm{dm} 3$.

For cations there were $24.51 \mathrm{mg} / \mathrm{dm} 3$ of calcium ions, $22.0 \mathrm{mg} / \mathrm{dm} 3$ natrium and calium ions and $19.87 \mathrm{mg} / \mathrm{dm} 3$ of magnesium ions. The relation of cations and anions - was HCO-3 > Cl- >SO2-4; $\mathrm{Ca} 2+>\mathrm{Na}++\mathrm{K}+>\mathrm{Mg} 2+$. The average hardness is $2.702 \mathrm{mg}$ - eq $/ \mathrm{dm} 3$.

Ih turgen waterfall: The average sum of its water ions $106.06 \mathrm{mg} / \mathrm{dm} 3$. For anions there were hydrocarbonate ions of $68.8 \mathrm{mg} / \mathrm{dm} 3$, sulphate ions is $1.3 \mathrm{mg} / \mathrm{dm} 3$, chloride ions of 

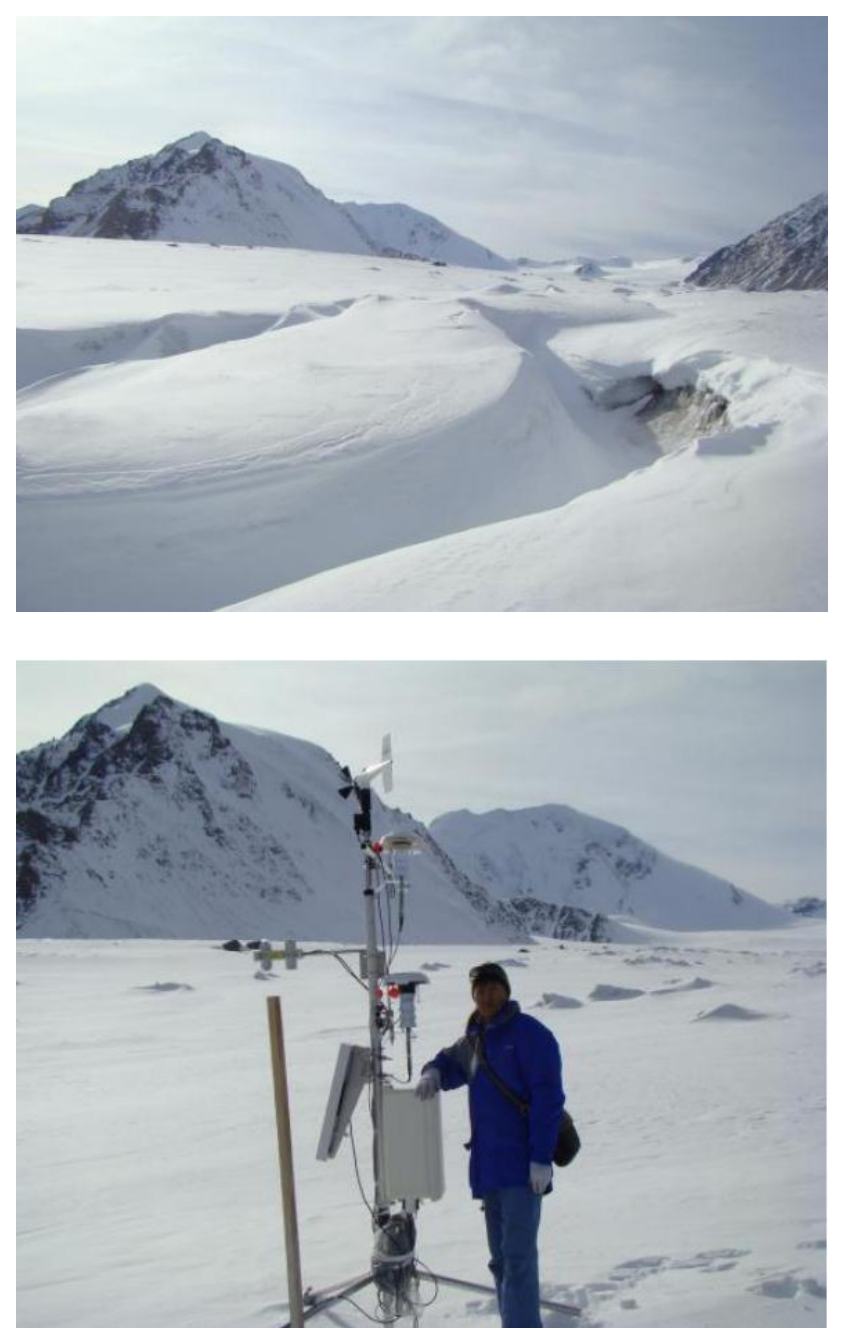

Picture 2. Potanin Ice River

$12.10 \mathrm{mg} / \mathrm{dm} 3$. For cations there were 22.0 $\mathrm{mg} / \mathrm{dm} 3$ of calcium ions, $5.75 \mathrm{mg} / \mathrm{dm} 3$ natrium and calium ions and $1.8 \mathrm{mg} / \mathrm{dm} 3$ of magnesium ions. The relation of cations and anions - was $\mathrm{HCO}-3$ > Cl- >SO2-4; $\mathrm{Ca} 2+>\mathrm{Na}++\mathrm{K}+>$ $\mathrm{Mg} 2+$. The average hardness is $1.26 \mathrm{mg}$ - eq /dm3.

Sogoo River. The average sum of its water ions $191.94 \mathrm{mg} / \mathrm{dm} 3$. For anions there were hydrocarbonate ions of $127.5 \mathrm{mg} / \mathrm{dm} 3$, sulphate ions is $2.4 \mathrm{mg} / \mathrm{dm} 3$, chloride ions of 13.60 $\mathrm{mg} / \mathrm{dm} 3$. For cations there were $30.0 \mathrm{mg} / \mathrm{dm} 3$ of calcium ions, $14.03 \mathrm{mg} / \mathrm{dm} 3$ natrium and calium ions and $4.8 \mathrm{mg} / \mathrm{dm} 3$ of magnesium ions. The relation of cations and anions - was HCO-3 > Cl- >SO2-4; $\mathrm{Ca} 2+>\mathrm{Na}++\mathrm{K}+>$ $\mathrm{Mg} 2+$. The average hardness is $1.9 \mathrm{mg}$ - eq /dm3.

Tolbo Lake. The average sum of its water ions $839.01 \mathrm{mg} / \mathrm{dm} 3$. For anions there were hydrocarbonate ions of $512.4 \mathrm{mg} / \mathrm{dm} 3$, sulphate ions is $40.3 \mathrm{mg} / \mathrm{dm} 3$, chloride ions of 64.10 $\mathrm{mg} / \mathrm{dm} 3$. For cations there were $30.0 \mathrm{mg} / \mathrm{dm} 3$ of calcium ions, $60.5 \mathrm{mg} / \mathrm{dm} 3$ natrium and calium ions and $24.9 \mathrm{mg} / \mathrm{dm} 3$ of magnesium ions. The relation of cations and anions - was HCO-3 > $\mathrm{Cl}->\mathrm{SO} 2-4 ; \mathrm{Na}++\mathrm{K}+>\mathrm{Ca} 2+>\mathrm{Mg} 2+$. The average hardness is $5.1 \mathrm{mg}-$ eq $/ \mathrm{dm} 3$. According to the classification of O.A.Alekin Tolbo lake belong to the group of hydrocarbonate with high mineralization, class of natrium and hardness water.

Hoton lake. The average sum of its water ions $141.54 \mathrm{mg} / \mathrm{dm} 3$. For anions there were hydrocarbonate ions of $106.90 \mathrm{mg} / \mathrm{dm} 3$, sulphate ions is $2.3 \mathrm{mg} / \mathrm{dm} 3$, chloride ions of $10.50 \mathrm{mg} / \mathrm{dm} 3$. For cations there were 19.60 $\mathrm{mg} / \mathrm{dm} 3$ of calcium ions, $17.15 \mathrm{mg} / \mathrm{dm} 3$ natrium and calium ions and $4.44 \mathrm{mg} / \mathrm{dm} 3$ of magnesium ions. The relation of cations and anions -was HCO-3 > Cl- >SO2-4; $\mathrm{Na}++\mathrm{K}+>$ $\mathrm{Ca} 2+>\mathrm{Mg} 2+$. The average hardness is 1.35 mg- eq /dm3.

Hurgan Lake. The average sum of its water ions $185.83 \mathrm{mg} / \mathrm{dm} 3$. For anions there were hydrocarbonate ions of $115.9 \mathrm{mg} / \mathrm{dm} 3$, sulphate ions is $20.1 \mathrm{mg} / \mathrm{dm} 3$, chloride ions of 17.70 $\mathrm{mg} / \mathrm{dm} 3$. For cations there were $23.80 \mathrm{mg} / \mathrm{dm} 3$ of calcium ions, $23.92 \mathrm{mg} / \mathrm{dm} 3$ natrium and calium ions and $2.50 \mathrm{mg} / \mathrm{dm} 3$ of magnesium ions. The relation of cations and anions - was $\mathrm{HCO}-3>\mathrm{Cl}->\mathrm{SO} 2-4$; $\mathrm{Na}++\mathrm{K}+>\mathrm{Ca} 2+$ $>\mathrm{Mg} 2+$. The average hardness is $1.4 \mathrm{mg}-\mathrm{eq}$ /dm3. According to the classification of O.A.Alekin Hoton and Hurgan lake belongs to the group of hydrocarbonate with low mineralization, class of calcium type of 1 water.

Sirgaaliin hooloi. The average sum of its water ions $178.04 \mathrm{mg} / \mathrm{dm} 3$. For anions there were hydrocarbonate ions of $110.6 \mathrm{mg} / \mathrm{dm} 3$, sulphate ions is $2.1 \mathrm{mg} / \mathrm{dm} 3$, chloride ions of 18.40 $\mathrm{mg} / \mathrm{dm} 3$. For cations there were $26.20 \mathrm{mg} / \mathrm{dm} 3$ of calcium ions, $16.79 \mathrm{mg} / \mathrm{dm} 3$ natrium and calium ions and $3.96 \mathrm{mg} / \mathrm{dm} 3$ of magnesium ions. The relation of cations and anions- was $\mathrm{HCO}-3>\mathrm{Cl}->\mathrm{SO} 2-4$; $\mathrm{Na}++\mathrm{K}+>\mathrm{Ca} 2+$ $>\mathrm{Mg} 2+$. The average hardness is $1.6 \mathrm{mg}$ $\mathrm{eq} / \mathrm{dm} 3$. According to the classification of O.A.Alekin Sirgaaliin hooloi belongs to the group of hydrocarbonate with low mineralization, class of calcium type of 1 water. The mineral content of Buraat River is the highest with $346.31 \mathrm{mg} / \mathrm{dm} 3$, and Altai Tavan Bogd is the lowest $94.84 \mathrm{mg} / \mathrm{dm} 3$ where the 
other rivers are varing between 141.64 and $282.68 \mathrm{mg} / \mathrm{dm} 3$. There is shown the ascilation of elements : $\mathrm{Cu}-0,0036-1,01 \mathrm{mg} / \mathrm{dm} 3, \mathrm{Ni}-$ $0.002 \mathrm{mg} / \mathrm{dm} 3, \mathrm{Mn}-0.0035-1.012 \mathrm{mg} / \mathrm{dm} 3, \mathrm{Al}-$ $0.020-1.270 \mathrm{mg} / \mathrm{dm} 3, \mathrm{Fe}-0.040-0.300$ $\mathrm{mg} / \mathrm{dm} 3, \mathrm{Zn}-0.001-1.014$ mg/dm3, Pb-0.030$0.094 \mathrm{mg} / \mathrm{dm} 3$, and $\mathrm{Ni} 0.0002 \mathrm{mg} / \mathrm{dm} 3$. The contents of all microelements were in the range of allowed amounts for trinking water.

Table 2. Water elements of Hovd river and its river bed.

\begin{tabular}{|c|c|c|c|c|c|c|c|c|c|c|c|}
\hline \multirow{2}{*}{$№$} & The point of & \multicolumn{8}{|c|}{ Elements $\mathrm{mg} / \mathrm{dm}^{3}$} \\
\cline { 3 - 12 } & sample & $\mathrm{Mn}$ & $\mathrm{Zn}$ & $\mathrm{Co}$ & $\mathrm{AI}$ & $\mathrm{Mo}$ & $\mathrm{Fe}$ & $\mathrm{Pb}$ & $\mathrm{Hg}$ & $\mathrm{Ni}$ & $\mathrm{Cu}$ \\
\hline 1 & $\begin{array}{c}\text { Hovd river (Bayn- } \\
\text { olgii aimag) }\end{array}$ & 0.0035 & 0.032 & 0.0003 & 0.100 & - & - & 0.036 & - & - & 0.003 \\
\hline 2 & Potanin ice river & 0.010 & 0.001 & 0.0002 & - & - & 0.150 & 0.054 & 0.002 & $\begin{array}{c}0.00 \\
2\end{array}$ & 0.014 \\
\hline 3 & Tsagaan river & 0.170 & 0.001 & - & 0.590 & 0.030 & 0.200 & 0.056 & - & - & 0.018 \\
\hline 4 & Ih uigariin gol & 1.012 & 1.014 & - & 1.270 & - & 0.300 & 0.054 & - & - & 1.013 \\
\hline 5 & $\begin{array}{c}\text { Tsengel sum } \\
\text { (Hovd river) }\end{array}$ & 0.012 & 0.014 & - & 0.020 & 0.030 & 0.040 & 0.094 & 0.002 & - & 0.013 \\
\hline
\end{tabular}

\section{CONCLUSIONS}

1. The water of Khovd River meets the requirements of MNS 0900-2005 for drinking water with its chemical composition and the physical properties. The refore the water of Khovd River best suites as drinking water for domestic and agricultural use.

2. Khovd and other rivers have low organic, medium carbon dioxide and high oxygen contents. Khovd River belongs to the group of hydrocarbonate and calcium type of low alkaline and medium mineralized water.

3. Khovd River is saturated with calcium carbonate in all seasons except summer and the carbon dioxide alkaline property is the highest in winter. But it is still not harmful for the river constructions.
4. Khovd river delivers 419.89 thousand tons of minerals to Khar us lake.

5. Khovd River has ecologically clean water with natural background.

\section{REFERENCES}

1. Alekin OA Basics of hydrochemistry. Gidrometeoizdat 1970. Стр. 53-164, 280318. ( in Russian)

2. Nikanorov AM Hydrochemistry. Gidrometeoizda 1989. Стр. 22-54, 87-116 ( in Russian)

3. Kolomiytseva MG, RD Gobovich Trace elements in medicine. 1970

4. Erdenechimeg.G Chemical composition and hydrochemical modelling of effuent of Hovd River Diss,Ulaanbaatar. 2008 